\title{
Perceived Service Quality Factors Influencing Undergraduate Students' Satisfaction at Universities in Java and Bali
}

\author{
Bonaventura Darryl1*, Indra Marhaendra ${ }^{1}$, Ida Bagus Gede Widana \\ Widiatmaka1', Kevin Pratama1', Tessa Natasha Fitriyanti ${ }^{1}$ \\ DOI: https://doi.org/10.36339/jaspt.v4i1.298
}

\section{Abstract}

The main objective of this research is to study the relationship between tangibility, trustworthiness, response capacity, guarantee, empathy, and innovative learning approach that affect the value of college students' satisfaction on the islands of Java and Bali. A quantitative study was conducted on students in various universities in Java and Bali, through a survey that was applied to the final sample of 205 students. Data analysis is carried out through structural equation modeling and shows that structures that affect students' satisfaction with the tertiary institutions where they study in the islands of Java and Bali are Guarantee, Tangibility, and Empathy factors.

Keywords: undergraduate students, perceived service quality, students' satisfaction, innovative learning approach

\begin{abstract}
Abstrak
Tujuan utama dari penelitian ini adalah untuk mempelajari hubungan antara tangibilitas, kepercayaan, kapasitas respon, jaminan, empati, dan pendekatan pembelajaran inovatif dalam mempengaruhi kepuasan mahasiswa di pulau Jawa dan Bali. Sebuah studi kuantitatif dilakukan pada siswa di berbagai universitas di Jawa dan Bali melalui survei yang diterapkan pada sampel sebanyak 205 mahasiswa. Analisis data dilakukan melalui pemodelan persamaan struktural, dan menunjukkan bahwa struktur yang mempengaruhi kepuasan mahasiswa dengan lembaga di mana mereka belajar di pulau Jawa dan Bali adalah faktor Jaminan, Tangibilitas, dan Empati.
\end{abstract}

Kata Kunci: mahasiswa, kualitas pelayanan, kepuasan mahasiswa, pendekatan pembelajaran inovatif

\footnotetext{
JAS-PT

JURNAL ANALISIS SISTEM PENDIDIKAN TINGG

ISSN 2580 - 5339

elSSN $2620-5718$

Volume 4

Nomor 1

JULI 2020

Hal $9-20$

FORUM DOSEN INDONESIA
}

In this current digital era, the rapid revolution of technology results in the emergence of
various applications that help speeding up and increasing operational processes. One of those affected by digitalization is the education sector. Education has an important

\section{INTRODUCTION}

of those affected by digtalization is the education sector. Education has an important 
role to catch up with the transformation, where there have been many changes in the role of school and education. Schools and universities are facing the key challenges linked to the impact and use of new technologies. In a digital society, technology has shaped and educated this generation of students.

The changes in the education sector encouraged greater competition among educational institutions. Educational institutions such as schools and universities realized the importance of students' satisfaction during the study process. Their satisfaction shows by the level of school/university influence in their competence. The level of students' satisfaction will determine the sustainability of the university in competing with an increasing number of Educational Institutions that offer attractive programs for prospective students.

It is important for the university to actively monitor the quality of services and protect the interests of stakeholders in general (students, parents, government, professional bodies), through meeting the needs and requirements of students. According to MarzoNavarro, Pedraja-Iglesias, Rivera-Torres (2005), positive perceptions about service quality can lead to students' satisfaction, which in turn can cause students to return to the University. This is one reason for this research, to know how students understand the quality of service, and how students' satisfaction is influenced by several things at the University, including:

1. Tangibility, where the physical factors of a university can affect the satisfaction of students, such as buildings, classrooms, school dossiers, staff curricula, paperwork, and supporting the learning process of other students.

2. Trustworthiness, a university can present many programs that support the advancement of students, such as external speakers, there is additional training for students, your documents, or professional practitioners from industry.

3. Response Capacity, the university has adequate capacity and ability to answer any student demands.

4. Guarantee, the university can provide confidence in students or applicants, by joining the university will have a better future.

5. Empathy, the university can position students on students until after they provide services that are in line with student expectations.

6. Innovative Learning Approach, where the methods of teaching and learning are consistent with the demands of the development of the times, as well as teachers who can provide teaching techniques which are easier to accept by students.

Research shows that Guarantee, Tangibility, and Empathy are the most important satisfaction factors for students. These factors may be related to the location of the research, universities in Java \& Bali. This outcome may be related to cultural life and values. And fact that school and university in Java and Bali have better ranks and qualifications than others. So that it will tend to be more in line with the expected demands.

In addition to this introduction, the paper continues with the second part which focuses on theoretical background and hypothesis development, highlighting significant

JAS-PT

JURNAL ANALISIS SISTEM PENDIDIKAN TINGGI ISSN $2580-5339$ eISSN $2620-5718$ Volume 4

Nomor 1

JULI 2020

Hal 9 - 20

FORUM DOSEN INDONESIA problems regarding the importance of the Tangibility, Trustworthiness factors, the ability of teachers to respond to students on target, the ability of universities to give confidence to students about the future, the university's ability to pay more attention to students, and the ability of the university to present up-to-date teaching techniques and in accordance with the conditions of the times and students' satisfaction. The third section explains research methods, including data collection, measurement, and statistical procedures. Section four highlights and discusses the main results of empirical studies. 
Finally, the final section concludes the study, presents the main theoretical and practical contributions along with some limitations and makes some suggestions for further research.

With the increasing demand for quality in higher education institutions in Indonesia, more attention is directed into various factors that affect the quality of an institution. A study conducted by Braskamp \& Ory (1994) concluded that students in higher education institutions were qualified to express their satisfaction or disappointment regarding teaching qualities.

O'Neill \& Palmer (2004) conducted a study about the difference between what services students were expecting to receive from school, and what services they received. The gap between these two variables is defined as service quality for higher educational institutions. Another study was also conducted to prove that service quality itself is not measured by a one-dimensional perspective, but based on various factors relevant to the context itself (Zeithaml et al, 2009).

Intangibility has been one of the hardest factors when it comes to measuring service quality. A method for measuring service quality was developed by Parasuraman, Zeithaml, and Berry (1985) based on a multiple-item scale. Ten factors of service quality were proposed to be applied to most service organizations (tangibility, reliability, responsiveness, courtesy, communication, competence, credibility, access, understanding, and security). Later Parasuraman, Zeithaml, and Berry (1988) narrowed down all 10 factors to 5 key factors, which are Tangibility, Trustworthiness, Response Capacity, Empathy, and Guarantee.

Researchers have been conducting studies to define students' satisfaction. Elliot \& Healy (2001) described it as an evaluation of students' educational experience. Petruzzellis, Uggento, and Romanazzi (2006) further explained that the experience escalates according to the number of services provided by the institution, and when there is a huge gap between perceived and expected services, negative experience occurs.

Alves and Raposo (2007) presented that satisfaction is affected directly by service quality. Meaning that students are satisfied when the factors of service quality perform well. (Sultan \& Wong, 2012). Pedro et al. (2018) studied the relationship between perceived quality (PQ) and satisfaction in higher education. This study shows that Perceived Quality is positively related to students' satisfaction in the Higher Education Institutions context.

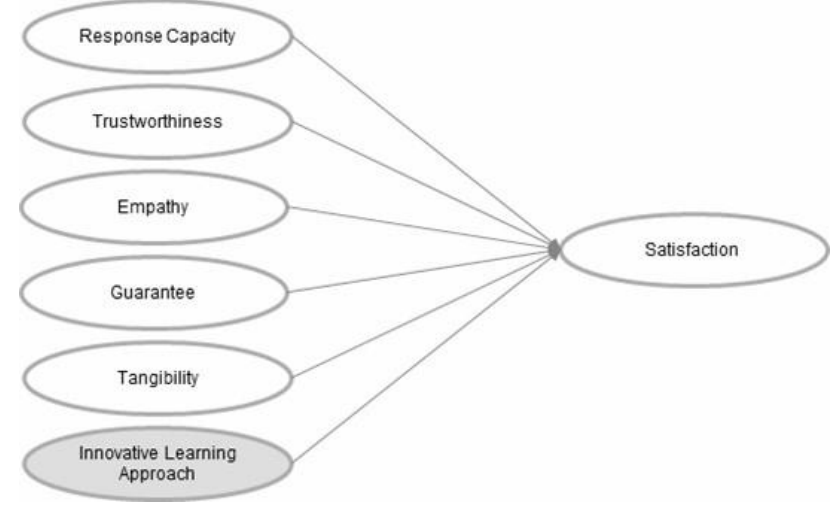

Figure 1. Research Model

Considering the above, we formulate the following research hypothesis: Hypothesis 1: Perceived Service Quality influences Students' Satisfaction positively. Therefore a second hypothesis can be concluded that:
JAS-PT

JURNAL ANALISIS SISTEM PENDIDIKAN TINGG ISSN $2580-5339$ eISSN $2620-5718$

Volume 4

Nomor 1

JULI 2020

Hal $9-20$

FORUM DOSEN INDONESIA 
Hypothesis 2: Tangibility, Trustworthiness, Response Capacity, Empathy, and Guarantee are positively influencing Students' Satisfaction

The conventional methods of high educational institutions are important for students' overall development (Yakovleva \& Yakovlev, 2014). However, a more business approach for universities is very important for today's rapidly changing educational ecosystem. (Gómez, Aranda, \& Santos, 2017).

Open innovation is a new method that opens up school resources to develop new products, processes, and services (Chesbrough, 2003). Other researches have also presented that the internal and external network can create innovations. Acquiring new technology and developing new and challenging business model can increase competitive advantages.

Inevitably, we have to implement open innovation into the education system. As we all know, school possesses a great number of external resources such as social networks. Cooperating with external resources does improve students' learning experience. Therefore, we intend to adopt the concept of open innovation and borrow perceived usefulness, ease of use, enjoyment, and comparative advantage from the technology acceptance model to develop an open, innovative, interactive, and interesting teaching approach.

The technology acceptance model (TAM) was made from the Rational Behavioral Theory and is widely implemented to describe factors of technology acceptance. Microsoft Encarta College Dictionary (2001) described the attitude as a perspective or general feeling about certain situations. Attitude is also regarded as a ready stance of psychology to act and react in nature response consciously or not (Benavides-Velasco and Quintana-Garcia 2008).

According to the above literature review, we can dive deeper into studies that focus on various innovative teaching methods in education and teacher's technology acceptance. Ping-Chang Lee et.al. (2015) expressed that an open innovative approach does have a positive influence on students' learning attitude and knowledge acquisition. While better learning attitudes and knowledge acquisition had a positive influence on learning intention. Also, learning intention increased students' satisfaction in learning.

Based on the above reasoning, we proposed the following research hypothesis: Hypothesis 3: Innovative Learning Approach positively influences students' learning satisfaction.

\section{METHOD}

\section{The relationship between perceived quality and satisfaction}

We conduct research on undergraduate students at various universities in Java (especially Jakarta) and Bali. We used a questionnaire consists of two main parts, namely personal data containing demographic data from the respondents, and the second part contained items related to variables used in this study, Perceived Quality and Satisfaction. Before distributing the questionnaire to the intended respondents, we

JAS-PT

JURNAL ANALISIS SISTEM PENDIDIKAN TINGG

ISSN $2580-5339$

eISSN $2620-5718$

Volume 4

Nomor 1

JULI 2020

Hal 9 - 20 conducted a pretest to 6 random people to ensure the questionnaire's readability and minimize bias of items in the questionnaire (Podsakoff, 2003). After making a few adjustments, the final questionnaire was sent to the respondents via email which included a link for filling out the questionnaire on the Google form. 
Tabel 1. The Indicators of Observed Variables

\begin{tabular}{|c|c|}
\hline Dimension & Item \\
\hline \multirow[t]{6}{*}{ Tangibility } & $\begin{array}{l}\text { T1.This university has appropriate physical infrastructure (comfortable, } \\
\text { airy, and well-lit). }\end{array}$ \\
\hline & $\begin{array}{l}\text { T2. This university has a Library with appropriate contents (quantity and } \\
\text { quality of books). }\end{array}$ \\
\hline & $\begin{array}{l}\text { T3. This university has appropriate laboratories (quantity and } \\
\text { characteristics of equipment). }\end{array}$ \\
\hline & $\begin{array}{l}\text { T4. This university has suitable technological resources (data } \\
\text { projectors, overhead projectors, computers etc.). }\end{array}$ \\
\hline & $\begin{array}{l}\text { T5. This university has appropriate and organized employees and } \\
\text { lecturers. }\end{array}$ \\
\hline & T6. University's lecturers use didactic material appropriately. \\
\hline \multirow{6}{*}{ Trustworthiness } & C7. This university promotes talks/seminars/workshops etc. \\
\hline & C8. This university promotes technical study visits. \\
\hline & C9. This university promotes university extension courses. \\
\hline & $\begin{array}{l}\text { C10. The subjects on my course are relevant for my professional } \\
\text { preparation. }\end{array}$ \\
\hline & C11. Lecturers balance theory and practice in the classroom. \\
\hline & $\begin{array}{l}\text { C12. Lecturers are skilled at awakening students' interest through } \\
\text { contents. }\end{array}$ \\
\hline \multirow[t]{2}{*}{$\begin{array}{l}\text { Response } \\
\text { Capacity }\end{array}$} & $\begin{array}{l}\text { CR13. The service provided by employees/specialists at this university } \\
\text { is appropriate (support offices, laboratories, library, etc). }\end{array}$ \\
\hline & CR14. Lecturers demonstrate sincere interest in helping students. \\
\hline \multirow{6}{*}{ Guarantee } & $\begin{array}{l}\text { G15. This university provides communication elements (notice-boards, } \\
\text { manuals, notices, e-mails, etc.) which keep students informed. }\end{array}$ \\
\hline & G16. Lecturers able to give satisfactory answers to students' questions. \\
\hline & G17. Lecturers master the subjects dealt with. \\
\hline & G18. Lecturers inspire confidence. \\
\hline & G19. Lecturers are fair when assessing students' performance. \\
\hline & $\begin{array}{l}\text { G20. Lecturers and non-teaching staff are always courteous to } \\
\text { students. }\end{array}$ \\
\hline \multirow{2}{*}{ Empathy } & E21. This university understands students' specific needs. \\
\hline & E22. Lecturers give students individualized attention. \\
\hline \multirow{6}{*}{$\begin{array}{l}\text { Innovative } \\
\text { Learning } \\
\text { Approach }\end{array}$} & ITA 23. Using mobile technology is a new teaching method. \\
\hline & ITA 24. Editing local culture material is a new teaching method. \\
\hline & ITA 25. Inviting experts to share their experiences. \\
\hline & ITA 26. Using e-learning as a teaching aid is a new teaching method. \\
\hline & ITA 27. Field trip is a new teaching method. \\
\hline & ITA 28. Video lecturing is a new teaching method. \\
\hline \multirow{6}{*}{ Satisfaction } & S29. In general, I am satisfied with the quality of my University. \\
\hline & S30. In general, for me it is a good University. \\
\hline & S31. In general, my University satisfies my needs \\
\hline & S32. Choosing this University to study in was a good decision. \\
\hline & $\begin{array}{l}\text { S33. In general, I am satisfied with the performance of the services } \\
\text { provided by my University. }\end{array}$ \\
\hline & general, I am satisfied \\
\hline
\end{tabular}

\section{Measurement and scales development}

This study aims to measure perceived service quality and the influence of various dimensions on students' satisfaction. Similar studies have been carried out before by other researchers (Pedro et al., 2018). In a previous study, perceived service quality

JAS-PT

JURNAL ANALISIS SISTEM PENDIDIKAN TINGG ISSN $2580-5339$ elSSN $2620-5718$

Volume 4

Nomor 1

JULI 2020

Hal $9-20$

FORUM DOSEN INDONESIA 
was measured against the (number of) students in the Faculty of Health Sciences at the University of Beira Interior (FHS-UBI) in Portugal through a construct consisting of 5 dimensions, these dimensions are (i) Tangibility ( 6 items), (ii) Trustworthiness ( 6 items), (iii) Response Capacity (2 items), (iv) Guarantee (6 items), and (v) Empathy (2 items). All items were measured using a 7-point Likert scale graded from 1 (completely disagree) to 7 (completely agree).

In the context of higher education, students' satisfaction is a psychological state of happiness that results from the performance evaluation of the service attributes (Sultan \& Wong, 2012). In this study, students' satisfaction was measured through a construct consisting of 5 items, referring to the main journal after adjustments, using a 7-point Likert scale graded from 1 (completely disagree) to 7 (completely agree). These items are as follows: (i) In general, I am satisfied with the quality of my University; (ii) In general, for me it is a good University; (iii) In general, my University satisfies my needs; (iv) Choosing this University to study in was a good decision; (v) In general, I am satisfied with the performance of the services provided by my University; and (vi) In general, I am satisfied with the value for money.

Complementing the five constructs measured in previous studies, the researcher added 1 (one) new construct that is expected to enrich understanding of the influence of various dimensions of service quality on students' satisfaction.

\section{RESULTS}

\section{Profile of respondents}

The total data collected are 205 respondents. Questionnaires were distributed and collected from 26 universities in Indonesia. Table 1 shows the respondents' profile summary of the research. Female is the majority of the respondents with $60.98 \%$ percentage and male is $39.02 \%$ percentage. Age of $17-20$ years old majoring the respondents with $62.93 \%$, this shows that the majority of the respondents are students in their first and second year in the university.

Table 2. Respondents' Profile Summary

\begin{tabular}{|l|l|c|c|}
\hline Variables & \multicolumn{1}{|c|}{ Description } & No. of Resp. & Percentage \\
\hline \multirow{2}{*}{ Gender } & Male & 80 & $39.02 \%$ \\
\cline { 2 - 4 } & Female & 125 & $60.98 \%$ \\
\hline \multirow{3}{*}{ Age } & $17-20$ years old & 129 & $62.93 \%$ \\
\cline { 2 - 4 } & $21-24$ years old & 69 & $33.66 \%$ \\
\cline { 2 - 4 } & 25 years old and older & 7 & $3.41 \%$ \\
\hline \multirow{2}{*}{ City } & Jakarta, Bogor, Depok, Tangerang, Bekasi & 142 & $69.27 \%$ \\
\cline { 2 - 4 } & Other Cities & 63 & $30.73 \%$ \\
\hline \multirow{2}{*}{ University } & Private University & 178 & $86.83 \%$ \\
\cline { 2 - 4 } & Public University & 27 & $13.17 \%$ \\
\hline
\end{tabular}

\section{Reliability Analysis}

JAS-PT

JURNAL ANALISIS SISTEM PENDIDIKAN TINGGI ISSN $2580-5339$ eISSN $2620-5718$

Volume 4

Nomor 1

JULI 2020

Hal 9 - 20

FORUM DOSEN INDONESIA
Below is Table 2 Cronbach's Alpha Reliability analysis. Six variables of Alpha value are higher than the accepted value of 0.70 , this indicates the items for each variable have relatively high internal consistency. There is only one variable in which the items have an Alpha value lower than 0.70 (reliability coefficient considered acceptable if the alpha value equals to 0.70 or above).

To check the correlation between construct and factor loading below are the details for each construct. For Tangibility, table 3 shows that all 6 items of tangibility are higher 
than 0.3 . This indicates good values for the tangibility construct. Variance, $\mathrm{KMO}$, and Alpha value for tangibility respectively are $0.603,0.858$, and 0.867 shows the strong value for the construct.

Table 3. Cronbach's Alpha Reliability

\begin{tabular}{|l|c|c|}
\hline \multicolumn{1}{|c|}{ Variables } & Alpha & N of items \\
\hline Tangibility & 0.867 & 6 \\
\hline Trustworthiness & 0.806 & 6 \\
\hline Response Capacity & 0.556 & 2 \\
\hline Guarantee & 0.867 & 6 \\
\hline Empathy & 0.824 & 2 \\
\hline Innovative Learning Approach & 0.847 & 6 \\
\hline Satisfaction & 0.956 & 6 \\
\hline
\end{tabular}

Table 4. Factor Analysis for Tangibility

\begin{tabular}{|c|c|c|c|c|}
\hline Tangibility & $\begin{array}{l}\text { Factor } \\
\text { Loading }\end{array}$ & $\begin{array}{l}\text { Explaine } \\
\quad \mathrm{d} \\
\text { Variance }\end{array}$ & KMO & Alpha \\
\hline $\begin{array}{l}\text { This university has appropriate physical } \\
\text { infrastructure (comfortable,airy,andwell-lit) }\end{array}$ & 3.619 & \multirow{6}{*}{0.603} & \multirow{6}{*}{0.858} & \multirow{6}{*}{0.867} \\
\hline $\begin{array}{l}\text { This university has a Library with } \\
\text { appropriate contents (quantity and quality } \\
\text { of books) }\end{array}$ & 0.802 & & & \\
\hline $\begin{array}{l}\text { This university has appropriate } \\
\text { laboratories (quantity and characteristics of } \\
\text { equipment) }\end{array}$ & 0.488 & & & \\
\hline $\begin{array}{l}\text { This university has suitable technological } \\
\text { resources (data projectors, overhead } \\
\text { projectors, computers etc.) }\end{array}$ & 0.407 & & & \\
\hline $\begin{array}{l}\text { This university has appropriate and } \\
\text { organized employees and lecturers. }\end{array}$ & 0.369 & & & \\
\hline $\begin{array}{l}\text { University's lecturers use didactic material } \\
\text { appropriately. }\end{array}$ & 0.315 & & & \\
\hline
\end{tabular}

Table 5. Factor Analysis for Trustworthiness

\begin{tabular}{|l|l|l|l|l|}
\hline Trustworthiness & $\begin{array}{l}\text { Factor } \\
\text { Loading }\end{array}$ & $\begin{array}{c}\text { Explaine } \\
\text { d } \\
\text { Variance }\end{array}$ & KMO & Alpha \\
\cline { 1 - 2 } $\begin{array}{l}\text { This university promotes } \\
\text { talks/seminars/workshops etc. }\end{array}$ & 3.106 & 0.517 & 0.787 & 0.806 \\
\cline { 1 - 2 } $\begin{array}{l}\text { This university promotes technical study } \\
\text { visits. }\end{array}$ & 1.043 & & & \\
\cline { 1 - 2 } $\begin{array}{l}\text { This university promotes university } \\
\text { extension courses. }\end{array}$ & 0.693 & & & \\
\cline { 1 - 2 } $\begin{array}{l}\text { The subjects on my course are relevant for } \\
\text { my professional preparation. }\end{array}$ & 0.526 & & & \\
\cline { 1 - 2 } $\begin{array}{l}\text { Lecturers balance theory and practice in } \\
\text { the classroom. }\end{array}$ & 0.345 & & & \\
\cline { 1 - 2 } $\begin{array}{l}\text { Lecturers are skilled at awakening } \\
\text { students' interest through contents. }\end{array}$ & 0.287 & & & \\
\hline
\end{tabular}

JAS-PT

UURAL ANALISIS SISTEM PENDIDIKAN TINGG ISSN $2580-5339$ eISSN $2620-5718$

Volume 4

Nomor 1

JULI 2020

Hal $9-20$

FORUM DOSEN INDONESIA 
For Trustworthiness, table 4 shows that 5 items of trustworthiness are higher than 0.3 . This indicates good values for the construct. Only 1 item excluded because the value is below 0.3. Variance, KMO, and Alpha value for Trustworthiness respectively are 0.517 , 0.787 , and 0.806 shows the strong value for the construct.

On table 5 , there is 1 item of Response capacity construct value that is above 0.3 . Explained variance, $\mathrm{KMO}$, and Alpha show a lower value than the parameter for each value.

Table 6. Factor Analysis for Response Capacity

\begin{tabular}{|l|l|l|l|l|}
\hline \multicolumn{1}{|c|}{ Response Capacity } & \multicolumn{1}{|c|}{$\begin{array}{c}\text { Factor } \\
\text { Loading }\end{array}$} & $\begin{array}{c}\text { Explaine } \\
\text { d } \\
\text { Variance }\end{array}$ & KMO & Alpha \\
\cline { 1 - 4 } $\begin{array}{l}\text { The service provided by employees/spe- } \\
\text { cialists at this university is appropriate } \\
\text { (support offices, laboratories, library, etc). }\end{array}$ & 1.385 & 0.692 & 0.500 & 0.556 \\
\cline { 1 - 3 } $\begin{array}{l}\text { Lecturers demonstrate sincere interest in } \\
\text { helping students. }\end{array}$ & 0.615 & & \\
\hline
\end{tabular}

On table 6 , there are 5 items of Guarantee construct value that are above 0.3 . Explained variance, $\mathrm{KMO}$, and Alpha show good value.

Table 7. Factor Analysis for Guarantee

\begin{tabular}{|c|c|c|c|c|}
\hline Guarantee & $\begin{array}{l}\text { Factor } \\
\text { Loading }\end{array}$ & $\begin{array}{l}\text { Explaine } \\
\text { d } \\
\text { Variance }\end{array}$ & KMO & Alpha \\
\hline $\begin{array}{l}\text { This university provides communication } \\
\text { elements (notice-boards, manuals, notices, } \\
\text { e-mails, etc.) which keep students } \\
\text { informed. }\end{array}$ & 3.655 & 0.609 & 0.843 & 0.000 \\
\hline $\begin{array}{l}\text { Lecturers are able to give satisfactory } \\
\text { answers to students' questions. }\end{array}$ & 0.789 & & & \\
\hline Lecturers master the subjects dealt with. & 0.556 & & & \\
\hline Lecturers inspire confidence. & 0.443 & & & \\
\hline $\begin{array}{l}\text { Lecturers are fair when assessing } \\
\text { students' performance. }\end{array}$ & 0.321 & & & \\
\hline $\begin{array}{l}\text { Lecturers and non-teaching staff are } \\
\text { always courteous to students. }\end{array}$ & 0.236 & & & \\
\hline
\end{tabular}

On table 6 , there is 1 item of Empathy construct value that is below 0.3 and 1 item is excluded. Explained variance and KMO values are 0.85 and 0.5 . The Alpha value is above 0.7 .

Table 8. Factor Analysis for Empathy

JAS-PT

JURNAL ANALISIS SISTEM PENDIDIKAN TINGGI

ISSN $2580-5339$

eISSN $2620-5718$

Volume 4

Nomor 1

JULI 2020

Hal 9 - 20

\begin{tabular}{|c|c|c|c|c|}
\hline Empathy & $\begin{array}{l}\text { Factor } \\
\text { Loading }\end{array}$ & $\begin{array}{c}\text { Explaine } \\
d \\
\text { Variance }\end{array}$ & KMO & Alpha \\
\hline $\begin{array}{l}\text { This university understands students' } \\
\text { specific needs. }\end{array}$ & 1.701 & \multirow[t]{2}{*}{0.850} & \multirow[t]{2}{*}{0.500} & \multirow[t]{2}{*}{0.824} \\
\hline $\begin{array}{l}\text { Lecturers give students individualized } \\
\text { attention. }\end{array}$ & 0.299 & & & \\
\hline
\end{tabular}


On table 7, there are 6 items of Innovative Learning Approach construct show good value as all the values are above 0.3 . Variance, $\mathrm{KMO}$, and alpha value respectively are $0.574,0.852$, and 0.847 .

Table 9. Factor Analysis for Innovative Learning Approach

\begin{tabular}{|c|c|c|c|c|}
\hline Innovative Learning Approach & $\begin{array}{l}\text { Factor } \\
\text { Loading }\end{array}$ & $\begin{array}{c}\text { Explaine } \\
\text { d } \\
\text { Variance }\end{array}$ & KMO & Alpha \\
\hline $\begin{array}{l}\text { Using mobile technology is a new teaching } \\
\text { method. }\end{array}$ & 3.449 & \multirow[t]{6}{*}{0.574} & \multirow[t]{6}{*}{0.852} & \multirow[t]{6}{*}{0.847} \\
\hline $\begin{array}{l}\text { Editing local culture material is a new } \\
\text { teaching method. }\end{array}$ & 0.762 & & & \\
\hline Inviting experts to share their experiences. & 0.621 & & & \\
\hline $\begin{array}{l}\text { Using e-learning as a teaching aid is a new } \\
\text { teaching method. }\end{array}$ & 0.492 & & & \\
\hline Field trip is a new teaching method. & 0.355 & & & \\
\hline Video lecturing is a new teaching method. & 0.321 & & & \\
\hline
\end{tabular}

On table 10, there are 2 items from the Satisfaction construct value are above 0.3 and the other 4 items are excluded because the value is below 0.3. Variance, KMO, and Alpha values show strong values.

Table 10. Factor Analysis for Satisfaction

\begin{tabular}{|c|c|c|c|c|}
\hline Satisfaction & $\begin{array}{l}\text { Factor } \\
\text { Loading }\end{array}$ & $\begin{array}{l}\text { Explaine } \\
\text { d } \\
\text { Variance }\end{array}$ & KMO & Alpha \\
\hline $\begin{array}{l}\text { In general, I am satisfied with the quality of } \\
\text { my University. }\end{array}$ & 4.991 & \multirow[t]{6}{*}{0.831} & \multirow[t]{6}{*}{0.924} & \multirow[t]{6}{*}{0.956} \\
\hline In general, for me it is a good University. & 0.310 & & & \\
\hline $\begin{array}{l}\text { In general, my University satisfies my } \\
\text { needs }\end{array}$ & 0.232 & & & \\
\hline $\begin{array}{l}\text { Choosing this University to study in was a } \\
\text { good decision. }\end{array}$ & 0.195 & & & \\
\hline $\begin{array}{l}\text { In general, I am satisfied with the } \\
\text { performance of the services provided by } \\
\text { my University. }\end{array}$ & 0.146 & & & \\
\hline $\begin{array}{l}\text { In general, I am satisfied with the value for } \\
\text { money. }\end{array}$ & 0.126 & & & \\
\hline
\end{tabular}

\section{Descriptive Analytics}

This research is using (Seven points Likert Scale) to measure each variable. Table 10 Descriptive Statistics shows minimum, maximum, and mean scores of each variable. The overall mean score for each variable is higher than 5 . This means all the variables are important factors for students' satisfaction studying in the universities.

Table 12 shows KMO score 0.949 , the score is higher than 0.5 which indicates the sample adequacy and Bartlett's Test of Sphericity Significant is below 0.05 .

JAS-PT

JURNAL ANALISIS SISTEM PENDIDIKAN TINGGI ISSN $2580-5339$ elSSN $2620-5718$

Volume 4

Nomor 1

JULI 2020

Hal $9-20$ 
Table 11. Descriptive Statistics

\begin{tabular}{|l|c|c|c|c|c|}
\hline & N & Min & Max & Mean & Std. Dev. \\
\hline Tangibility & 205 & 2.17 & 7.00 & 5.65 & 0.90 \\
\hline Trustworthiness & 205 & 1.83 & 7.00 & 5.47 & 0.92 \\
\hline Response & 205 & 1.00 & 7.00 & 5.49 & 1.08 \\
\hline Guarantee & 205 & 1.83 & 7.00 & 5.55 & 0.95 \\
\hline Empathy & 205 & 1.00 & 7.00 & 5.11 & 1.39 \\
\hline Innovative & 205 & 1.67 & 7.00 & 5.43 & 1.05 \\
\hline Satisfaction & 205 & 1.00 & 7.00 & 5.55 & 1.26 \\
\hline Valid N (listwise) & 205 & & & & \\
\hline
\end{tabular}

Table 12. KMO and Bartlett's Test

\begin{tabular}{|l|l|l|}
\hline Kaiser-Meyer-Olkin Measure of Sampling Adequacy. & 0.949 \\
\hline Bartlett's Test of Sphericity & Approx. Chi-Square & 5687.29 \\
\cline { 2 - 3 } & df & 561 \\
\cline { 2 - 3 } & Sig. & 0.00 \\
\hline
\end{tabular}

\section{Test of Hypotheses}

Table 13 shows Tangibility Sig value $0<0.05$, Guarantee Sig value $0.005<0.05$, and Empathy sig value $0.001<0.05$ means these three variables influence Students' satisfaction studying in Indonesia's University. Trustworthiness, Response Capacity, and Innovative Teaching Approach Sig values above 0.05 show insignificant or not influence the students' satisfaction studying in Indonesia's universities.

Table 13. Regression Results

\begin{tabular}{|l|l|c|c|c|c|}
\hline Hypothesis & Beta & t & sig & \multicolumn{1}{|c|}{ Result } \\
\hline Tangibility & $\begin{array}{l}\text { Students' } \\
\text { satisfaction }\end{array}$ & 0,46 & 4,567 & 0,000 & influence satisfaction \\
\hline Trustworthiness & $\begin{array}{l}\rightarrow \text { Students' } \\
\text { satisfaction }\end{array}$ & $-0,024$ & $-0,234$ & 0,815 & $\begin{array}{l}\text { not influence } \\
\text { satisfaction }\end{array}$ \\
\hline $\begin{array}{l}\text { Response } \\
\text { Capacity }\end{array}$ & $\begin{array}{l}\text { Students' } \\
\text { satisfaction }\end{array}$ & 0,139 & 1,439 & 0,152 & $\begin{array}{l}\text { not influence } \\
\text { satisfaction }\end{array}$ \\
\hline Guarantee & $\begin{array}{l}\rightarrow \\
\text { Students' } \\
\text { satisfaction }\end{array}$ & 0,317 & 2,866 & 0,005 & influence satisfaction \\
\hline Empathy & $\begin{array}{l}\text { Students' } \\
\text { satisfaction }\end{array}$ & 0,19 & 3,315 & 0,001 & influence satisfaction \\
\hline $\begin{array}{l}\text { Innovative } \\
\text { Learning } \\
\text { Approach }\end{array}$ & $\begin{array}{l}\text { Students' } \\
\text { satisfaction }\end{array}$ & 0,052 & 0,639 & 0,524 & $\begin{array}{l}\text { not influence } \\
\text { satisfaction }\end{array}$ \\
\hline
\end{tabular}

JAS-PT

JURNAL ANALISIS SISTEM PENDIDIKAN TINGG

ISSN $2580-5339$

eISSN $2620-5718$

Volume 4

Nomor 1

JULI 2020

Hal 9 - 20

FORUM DOSEN INDONESIA
In this research to test the influence of the 5 independent variables with dependent variables, multiple regression test was used. All of the five independent variables are Tangibility, Trustworthiness, Response Capacity, Guarantee, Empathy, and Innovative Teaching Method. The dependent variable in the research is satisfaction. We test what variables influence the satisfaction of university students in Indonesia. The R-Squared 
value of the model was 0.694 as shown in table 13.0 ANOVA, the value is indicating adequate goodness of fit (Read, 1998).

Table 14. ANOVA

\begin{tabular}{|l|l|l|l|l|}
\hline Model & R & R Square & Adj. R Square & $\begin{array}{l}\text { Std. Error of the } \\
\text { Estimate }\end{array}$ \\
\hline 1 & $0.83^{\mathrm{a}}$ & 0.694 & 0.685 & 0.708 \\
\hline $\begin{array}{l}\text { a. Predictors: (Constant), Innovative, Empathy, Tangibility, Trustworthiness, } \\
\text { Response, Guarantee }\end{array}$
\end{tabular}

\section{CONCLUSIONS}

Our study's main aim was to explore the relationship between perceived quality and satisfaction, especially analyzing how these constructs affect students' satisfaction. Briefly, our results indicate that the perceived service quality factors that most influence the satisfaction of undergraduate students in Indonesia, especially Java and Bali, are Tangibility, Guarantee, and Empathy. While the other three factors, namely Trustworthiness, Response Capacity, and Innovative Teaching Approach did not affect the level of students' satisfaction. These statements have proven our First Hypothesis (H1) true regarding the positive correlation between Service Quality and Students' Satisfaction, but not entirely proven our Second Hypothesis (H2), because not all five factors of SERVQUAL were able to influence students' satisfaction especially in the specified group of samples. Our Third Hypothesis $(\mathrm{H} 3)$ regarding Innovative Teaching Approach having a positive correlation with Student's Satisfaction was also not proven, because the impact was not significant.

This shows that physical matters still play an important role in students' satisfaction. In addition, other supporting matters such as communication processes and interactions between lecturers and other university staff and students become the next important thing that determines undergraduate students' satisfaction.

Literature in general, and especially in the marketing field, has already proven that satisfaction is a key element to reaching students' loyalty. Thus, to retain and recruit students, the university should direct significant efforts to enhance students' satisfaction. To increase students' satisfaction, the university needs to improve the quality of services provided to its students. Our study is particularly useful for university by emphasizing the relevant service quality dimensions and related attributes on which university should concentrate their efforts and avoid wasting valuable resources in services that could be referred to as peripheral.

Thus, administrative efforts should be directed at improving the teaching environment, including selecting the appropriate teaching staff or providing the necessary resources to this staff to be able to actuate as expected by students. Since those issues are few things that can be controlled easily by the university, improvements in these issues may represent an added value to the university and a differentiating element from their direct competitors.

Despite the significance of the results, we must highlight that our research was conducted only in several regions in Indonesia. This is certainly a limitation of this study, as one may not generalize the results to all Indonesia universities in general, and even less to the student population as a whole. Notwithstanding this limitation, the study provides noteworthy findings and provides the groundwork for further research on the relationship between services perceived quality and satisfaction in the context of the

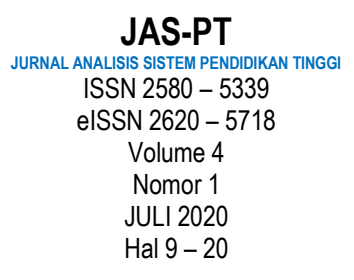

FORUM DOSEN INDONESIA 
university, as well as how this relationship can differ between groups of undergraduate students and other groups such as post-graduate students.

\section{REFERENCES}

Alves, H., \& Raposo, M., 2007. Conceptual model of student satisfaction in higher education. Total Quality Management, 18(5), 571-588.

Benavides-Velasco, C.A., Quintana-Garcia, C., 2008. Innovative competence, exploration and exploitation: the influence of technological diversification. Res. Policy 37(3), 492-507.

Braskamp, L. A., \& Ory, J. C., 1994. Assessing faculty work: Enhancing individual and instructional performance. San Francisco, CA: Jossey- Bass.

Chesbrough,H.W., 2003. : Open Innovation: TheNewImperative forCreating and Profiting fromTechnology.Harvard Business School Press, Boston.

Elliott, K. M., \& Healy, M. A., 2001. Key factors influencing student satisfaction related to recruitment and retention. Journal of Marketing for Higher Education, 10(4), 1-11.

Gómez, M., Aranda, E., \& Santos, J., 2017. A competency model for higher education: an assessment based on placements. Studies in Higher Education, 42(12), 2195-2215.

O'Neill, M. A., \& Palmer, A., 2004. Importance-performance analysis: a useful tool for directing continuous quality improvement in higher education. Quality Assurance in Education, 12(1), 39-52.

Parasuraman, A., Zeithaml, V. A., \& Berry, L. L., 1985. A conceptual model of service quality and its implications for future research. Journal of Marketing, 49, 4150.

Parasuraman, A., Zeithaml, V. A., \& Berry, L. L., 1988. SERVQUAL: a multiple-item scale for measuring consumer perceptions of service quality. Journal of Retailing, 64(1), 12-40.

Pedro, E., Mendes L., \& Lourenco, L., 2018. Perceived Service Quality and Student's Satisfaction in Higher Education: The Influence of Teaching Methods. International Journal for Quality Research 12(1) 165-192 (2018).

Petruzzellis, L., D'Uggento, A. M. \& Romanazzi, S., 2006. Student Satisfaction and Quality of Service in Italian Universities, Managing Service Quality, 16(4). 349-364.

Ping-Chang Lee, Cheng-ta Lin, \& Hsin-Hong Kang, 2015. The influence of open innovative teaching approach toward student satisfaction: a case of Si-Men Primary School. Springer Science+ Business Media Dordrecht (2015).

Purba, J.H.V., Ratodi, M., Mulyana, M., Wahyoedi, S., Andriana, R., Shankar, K. and Nguyen, P.T., 2019. Prediction Model in Medical Science and Health Care. International Journal of Engineering and Advanced Technology, 8, pp.815818.

JAS-PT

ANALISIS SISTEM PENDIDIKAN TINGGI

ISSN $2580-5339$

eISSN $2620-5718$

Volume 4

Nomor 1

JULI 2020

Hal 9 - 20

Sultan, P., \& Wong, H., 2010. Performance-based service quality model: an empirical study on Japanese universities. Quality Assurance in Education, 18(2), 126143.

Yakovleva, N. O., \& Yakovlev, E. V., 2014. Interactive teaching methods in contemporary higher education. Pacific Science Review, 16(2), 75-80.

Zeithaml, V. A., Gremler, D. D., \& Bitner, M. J., 2009. Services marketing: integrating customer focus across the firm (5th ed.). London: McGraw- 